\title{
FORMAÇÃO DE DOCENTES A DISTÂNCIA: REFLEXÕES SOBRE UM PROGRAMA
}

\author{
ELBA SIQUEIRA DE SÁ BARRETTO, REGINA PAHIM PINTO \\ e ANGELA MARIA MARTINS \\ Fundação Carlos Chagas
}

\begin{abstract}
RESUMO
Este artigo pretende analisar os resultados alcançados em duas avaliações realizadas sobre o Programa de Educação a Distância intitulado "Um Salto para o Futuro", em 1992 e 1997, respectivamente. Ambos os estudos guiaram-se sobretudo pelo intuito de destacar aspectos fundamentais do modelo de ensino a distância desenvolvido pelo Programa, tendo em conta o fato de que a sua concepção e o teste de realidade por que passou têm muito a acrescentar à experiência nacional sobre o assunto.

EDUCAÇÃO A DISTÂNCIA - FORMAÇÃO DE DOCENTES - PROGRAMAS EDUCACIONAIS PROGRAMASALTO PARA O FUTURO
\end{abstract}

\footnotetext{
ABSTRACT

EXTENSION TRAINING FOR TEACHER: REFLECTIONSONAPROGRAM. This article analyzes the results achieved in two evaluations of the Educational Extension Program titled "A Leap for the Future", carried out in 1992 and 1997 respectively. Both studies are guided by the aim of underlining aspects fundamental to the extension teaching model developed by the Program, taking into account the fact that the process of conception and the reality testing it has undergone has much to add to the national experience on the subject.
} 
A educação a distância constitui uma modalidade específica de ensino, em que o tempo de produção é separado do tempo de uso e que se processa sem que as reações dos alunos possam ser contornadas pela improvisação do professor. A interação professor-aluno efetiva-se intermediada por algum meio, recurso ou material, estrategicamente elaborado, para estimular o aluno à auto-aprendizagem. Como modalidade de ensino, assume portanto, papel ativo na assimilação dos conteúdos. Pode ser dirigida a grupos de aprendizagem ou indivíduos (Costa, 1994. p.42).

A primeira modalidade de educação a distância foi a dos cursos por correspondência, iniciados na Europa a partir de fins do século XIX. A ela seguiu-se a introdução do rádio e, no meio deste século, da televisão. Atualmente, a terminologia "educação a distância" define uma série de tecnologias alternativas sofisticadas com a utilização de ferramentas tais como e-mail, Broadcast Bulletin Systems - BBS's, Internet, audioconferências por telefone, videoconferências com um ou dois caminhos de vídeo e dois caminhos de áudio.

Nos países desenvolvidos os programas de educação a distância têm sido considerados nos últimos vinte anos como uma alternativa de atendimento à população adulta, excluída das modalidades tradicionais de ensino ou demandatária de programas de capacitação continuada. Nesses países, instituições de ensino superior têm se dedicado a prover educação a distância no nível pós-secundário, tais como a United Kingdom's Open University, na Inglaterra e a Vancouver's Open Learning Agency, no Canadá, apenas para citar dois exemplos conhecidos. Mais recentemente, essa tendência começa a se instalar no ensino médio. O programa que hoje melhor expressa a perspectiva de atendimento a estudantes desse nível de ensino é desenvolvido pelo governo federal dos Estados Unidos - Star School Program.

No contexto latino-americano, as décadas de setenta e oitenta assistiram à expansão de programas de educação a distância. Eles buscaram responder às dificuldades demonstradas pelos sistemas de ensino para atenderem, via modalidade tradicional, às crescentes solicitações educacionais de segmentos que, por força das demandas de mercado, têm procurado obter a escolaridade exigida para ingresso no mundo do trabalho ou almejam uma mudança na qualificação profissional.

As vantagens dessa modalidade alternativa para superar as limitações das aulas convencionais devem-se a inúmeros fatores (Gutierrez, Prieto, 1994. p. 12). Em primeiro lugar, aumentam as chances de atendimento a um público diversificado, incluindo-se aí a educação permanente de adultos. Há uma relativização das fronteiras geográficas e, em princípio, uma diminuição de custo por estudante, ampliando-se a possibilidade de democratização do ensino. Os ritmos diferenciados de aprendizagem podem ser mais respeitados do que nas aulas presenciais, em decorrência do desenvolvimento da capacidade de autodidatismo. Isso, no entanto, nem sempre ocorre em virtude da prevalência da cultura e dos condicionantes administrativos derivados do sistema de ensino presencial, particularmente nos programas governamentais (idem. p. 13). Paradoxalmente, as vantagens desses programas transformamse muitas vezes em riscos durante o processo de implementação. Em alguns casos, eles 
podem aproximar-se dos paradigmas do mundo da produção, desenvolvendo uma concepção excessivamente padronizada que impede ou dificulta a adoção de um modelo interativo.

\section{A EDUCAÇÃO A DISTÂNCIA NO BRASIL}

A educação a distância no país teve também origem no século passado, com o ensino por correspondência, e tem possibilitado uma melhor inserção de milhares de pessoas residentes em cidades do interior e áreas marginalizadas no mercado de trabalho. $\bigcirc$ rádio foi o segundo recurso utilizado, sendo que a radiodifusão, com finalidade educativa, inicia-se em 1923, com a fundação da Rádio Sociedade do Rio de Janeiro, por Edgard Roquette-Pinto. Nas décadas de cinqüenta e sessenta, surgem vários projetos de radiodifusão entre os quais destacam-se os programas voltados para a Educação de Base (Movimento de Educação de Base - MEB), organizados pela Conferência Nacional dos Bispos do Brasil, visando alfabetizar as massas e desenvolver entre elas habilidades intelectuais e sociais. Vários desses programas não tiveram, entretanto, continuidade. Diversos fatores contribuíram para a sua interrupção: inexistência de infra-estrutura financeira e administrativa, deficiência técnica, ausência de avaliações sistemáticas, desconhecimento de conteúdos (Niskier, 1988).

Nos anos cinqüenta, introduz-se a TV em circuito aberto, época em que também foram registradas as primeiras experiências em circuito fechado, na Universidade de Santa Maria, no Rio Grande do Sul ( 1958). Em 1960, a Universidade de Brasília introduz a tecnologia educacional no ensino superior por meio do ensino programado individualizado. Segundo Niskier (1988), essa foi uma oportunidade para o treinamento dos professores que constituíam a equipe docente da universidade.

Sedimentam-se também nessa fase as experiências relativas à Radiodifusão Educativa e são tomadas algumas medidas oficiais: reserva federal pelo Conselho Nacional de Telecomunicações - Contel - de emissoras para canais de televisão e a criação da Fundação Centro Brasileiro de Televisão Educativa em 1967. Devido à extensão e ao porte das suas atividades, esta transformou-se em Fundação Nacional de Televisão Educativa —Funtevê.

Concorreu igualmente para a expansão da tecnologia educacional no Brasil, a filiação do país à Organização dos Estados Americanos — OEA — , entidade que preconizava aos países membros a priorização de programas educativos de radiodifusão e televisão, considerados meios eficientes para acelerar a transformação social. Recomendava-se, também, a formação de pessoal nas técnicas de utilização de rádio e televisão educativas e a promoção de uma coordenação permanente para evitar a dispersão de recursos nos campos educacional, tecnológico e econômico. Foi exatamente na Conferência Internacional da OEA, em 1969, que o termo teleducação, abrangendo todas as atividades educativas pelo rádio, televisão e outros meios audiovisuais a distância, passou a ser adotado pelos países membros.

Em 1969, cria-se o Sistema Avançado de Tecnologias Educacionais — SATE —, com 
o objetivo de fixar diretrizes para uma política de aplicação de novas tecnologias educacionais no país - rádio, televisão e outros meios. Nesse contexto, foram desenvolvidos projetos educacionais destinados aos cursos supletivos, como o Minerva, que proporcionou a interiorização da educação básica por meio da Rádio MEC, e os telecursos de primeiro e segundo graus. Desenvolveram-se igualmente projetos voltados à melhoria do nível do professorado como o Projeto Saci, os da Funtevê e o Logos.

Outro marco importante na introdução da tecnologia educacional no sistema de ensino brasileiro pode ser localizado na lei 5692/7I. No capítulo dedicado ao ensino supletivo, art. 25 , parágrafo $2^{\circ}$, ela recomendava a utilização da tecnologia da comunicação nos cursos destinados à educação de jovens e adultos. Era a época do "milagre brasileiro", momento marcado por intenso processo de industrialização. A crença da tecnoburocracia dirigente nas potencialidades da tecnologia aplicada à educação como a maneira mais rápida de incorporar, a baixo custo, grande contingente da população jovem e adulta com reduzida ou nenhuma escolarização ao setor produtivo e aos esforços de desenvolvimento nacional, teve por conseqüência a multiplicação de iniciativas nessa linha. Tratava-se então, no dizer de Niskier (apud Magalhães, 1997), de destinar a tecnologia educacional a cursos considerados inferiores, para grupos sociais de menor prestígio.

A despeito da importância de algumas das iniciativas desse período, sua avaliação indicava diversos pontos de estrangulamento: várias linhas de ação, falta de integração e inexistência de uma estratégia do governo na área. Objetivando sanar esses problemas, criase em 1972, o Programa Nacional de Teleducação - Prontel -, vinculado à Secretaria Geral do MEC. Ele constituiu a primeira tentativa de estabelecimento de diretrizes para a televisão e terminou transformando-se em organismo permanente dentro da estrutura orgânica do ministério (Fradkin, 1981).

Apesar de muitas das experiências de educação a distância terem sido bem-sucedidas, por várias razões, entre as quais freqüentemente a falta de recursos financeiros ou de vontade política, não tiveram continuidade. Como exceção, no âmbito do setor público, destacam-se a experiência da TV Educativa do Maranhão, fundada em 1969 e atuando até hoje no ensino das $5^{\mathrm{a}}$ às $8^{\mathrm{a}}$ séries do primeiro grau, e a da antiga Funtevê.

A partir de 1990, a Funtevê passou a ser denominada Fundação Roquette-Pinto, integrada ao Sistema Nacional de Radiodifusão Educativa — Sinred, o qual engloba as redes que operam no território nacional.

Outras instituições vêm igualmente desenvolvendo vários programas, entre as quais vale mencionar as TVs Educativas dos Estados do Rio Grande do Norte e Ceará, a Fundação Padre Anchieta de São Paulo, o Serviço Nacional do Comércio — Senac —, a Associação Brasileira de Tecnologia Educacional, a Fundação Roberto Marinho que, mais recentemente, produziu o Telecurso 2000 para o primeiro e segundo graus, em convênio com a Federação das Indústrias do Estado de São Paulo. A universidade de Brasília adquiriu também uma larga 
experiência em educação a distância com cursos de extensão, que se iniciaram em 1979. Tal experiência deu origem ao Centro de Educação Aberta Continuada a Distância, criado em 1989 (Saraiva, 1996).

Nos anos noventa, dois programas de âmbito nacional passam a constituir importantes marcos referenciais da educação a distância no país. São eles: "Um Salto para o Futuro" e "TV Escola", ambos voltados para o aperfeiçoamento de docentes e melhoria da qualidade do ensino. $\bigcirc$ primeiro, criado na primeira metade da década, será objeto de análise deste artigo. O segundo, lançado via satélite em 1995, por meio de um canal de televisão dedicado exclusivamente à educação, gera três horas de programação diária repetida quatro vezes ao dia, permitindo que as escolas gravem os programas de seu interesse para posterior utilização (Saraiva, 1996).

Nesta década, o governo brasileiro, por meio dos Ministérios da Educação e das Comunicações, vem tomando concomitantemente uma série de medidas para consolidar uma política de educação a distância. Com esse propósito, tem envolvido o Conselho de Reitores das Universidades Brasileiras - Crub —, o Conselho de Secretários da Educação - Consed - e a União Nacional de Dirigentes Municipais - Undime.

\section{A formação de docentes a distância}

A educação a distância figura com destaque nos marcos legais contemporâneos e nos planos de educação do país. A Constituição de 1988, no seu artigo 221 , refere-se à emissão de programas de televisão e rádio com finalidades educativas e culturais e a nova Lei de Diretrizes e Bases da Educação Nacional (9.394/96), estabelece, no art. 80, as diretrizes a serem seguidas pelo poder público para "incentivar o desenvolvimento de programas de educação a distância, em todos os níveis e modalidades, e de educação continuada".

Tanto o Plano Decenal de Educação Para Todos, elaborado em 1993 com vistas à universalização do ensino fundamental e erradicação do analfabetismo, como os projetos do Plano Nacional de Educação, ora em tramitação no Congresso, mencionam a educação a distância como parte da utilização de novas tecnologias de comunicação e informação, que necessariamente têm de ser consideradas no processo educativo. Reconhecem também que a revolução nas comunicações introduz uma nova lógica ao trabalho pedagógico e demanda uma reorientação do processo de aquisição do conhecimento.

A propósito, a nova Lei de Diretrizes e Bases - LDB - abre ainda imensas possibilidades de proliferação da educação a distância, ao determinar, entre outras coisas, que a formação dos professores de todos os níveis do ensino básico seja feita em nível superior. Para tanto, fixa o prazo de cinco anos para que todos os professores de educação infantil e de primeira a quarta séries tenham certificado de curso normal, determinando que, nesse período, os estados que possuam professores leigos completem a formação em nível médio desses profissionais. O prazo para que todos os professores adquiram o nível superior é de dez anos. 
Além das iniciativas no sentido de que essas determinações se concretizem, as exigências de melhoria de qualidade da educação básica postas na LDB, impõem a realização de programas de formação continuada de todos os professores, incluindo os que já possuem a qualificação acadêmica requerida, uma vez que necessitam de atualização.

Entre cerca de 800 mil funções docentes de primeira a quarta séries do ensino fundamental arroladas pelo censo escolar em 1998 (Brasil, SEEC/MEC, 1998)' apenas 2 1\% são exercidas por professores com formação superior, nível preconizado pela nova legislação, sem contar que I I\% do total correspondem a professores com apenas o curso de primeiro grau. Se aos docentes das séries iniciais do ensino fundamental acrescentarem-se os das quatro séries seguintes (54\% sem curso superior) e os dedicados à educação infantil, também insuficientemente preparados, estaremos certamente diante de um dos maiores desafios educacionais da virada do século.

Considerando que o ensino fundamental está quase universalizado e que a população cresce a taxas reduzidas de natalidade, não se espera grande expansão de matrículas no ensino obrigatório, de sorte que é provável que as redes de ensino não contratem grande número de novos professores, devendo sobretudo preocupar-se com a requalificação de seus quadros docentes. Ainda que a formação inicial seja sumamente importante, é pois de se esperar um esforço muito grande e articulado de todas as instâncias administrativas e das instituições de ensino superior nos próximos anos para lograr que os professores atinjam um patamar mais elevado de qualificação profissional.

Nesse sentido, a LDB, em seu artigo 63, chega explicitamente a prever programas de educação continuada para os profissionais da educação, o que requer inevitavelmente a utilização, entre outros, dos recursos da educação a distância, dada a quantidade de profissionais a atingir. Requer também a criação de novos modelos de formação, que superem a fragmentação dos programas existentes e que estabeleçam ligações mais explícitas entre os contratos de trabalho, formação em serviço e exercício docente.

A maior parte das iniciativas de educação a distância em andamento no país está vinculada aos meios modernos de comunicação e, conforme adverte Garcia (1997), assenta-se numa perspectiva salvacionista,

[...] de recuperação do tempo perdido e de aceleração do atendimento de demandas não contempladas em seu devido momento. Esse apelo ao moderno, no sentido de novo, funciona como um catalizador de elevação da auto-estima, frente a uma realidade pobre e com poucas perspectivas de transformação. (p. 16)

A ênfase é deslocada equivocadamente para o meio educativo, como se ele fosse o fator relevante dessa forma de educação.

I. O censo escolar refere-se a funções docentes e não a professores propriamente ditos. Um professor que leciona em mais de um curso, ou período, exerce mais de uma função docente. 
Em que pesem as possibilidades postas pela moderna tecnologia e pela educação a distância, as experiências com essa modalidade de ensino ao longo das últimas décadas têm mostrado algumas de suas virtudes, mas também muitas das suas limitações. Seu emprego tem sido mais eficaz quando dirigido àqueles que já têm melhor nível educacional e tem se revelado particularmente proveitoso na formação continuada de profissionais mais escolarizados. A educação a distância não dispensa, pelo contrário, reforça o uso de textos escritos e das atividades presenciais, ou seja, de recursos associados às formas tradicionais de ensino. O domínio de um instrumental básico de comunicação por parte dos profissionais, aos quais se dirige a educação a distância, oferece-lhes possibilidades de melhor utilizarem os componentes de autodidaxia, em geral envolvidos nesses programas. Além disso, o esforço desses profissionais pode ser estimulado pela motivação de melhorar o desempenho em serviço.

\section{O PROGRAMA "UM SALTO PARA O FUTURO"}

"Um Salto para o Futuro" é um programa de educação a distância, produzido pela Fundação Roquette-Pinto em parceria com o Ministério da Educação e Cultura/Secretaria de Educação Básica — MEC/Seneb. Destina-se prioritariamente à capacitação de professores de $I^{\mathrm{a}}$ a $4^{\mathrm{a}}$ séries do ensino fundamental, mas pode ser estendido também aos docentes de préescola e aos alunos de cursos de magistério. Seu público-alvo é, portanto, o professor com formação básica de nível médio.

Criado em 1992, o programa é produzido pelo governo federal e implementado em ação compartilhada com estados e municípios. Faz parte do esforço de melhoria do sistema educacional brasileiro, mediante o emprego de ações não tradicionais, voltadas para a formação continuada dos docentes. Propõe-se a contribuir para que o professor chegue à formulação de um referencial teórico-metodológico adequado às séries iniciais do ${ }^{\circ}$ grau e à préescola, bem como amplie e atualize seu nível geral de conhecimento.

O programa apóia-se em material impresso, enviado com antecedência aos cursistas e em transmissões televisivas nas quais são utilizados vídeos versando sobre os temas da aula e veiculados comentários de especialistas sobre os conteúdos abordados. Possui também uma parte interativa em que os especialistas debatem com a audiência respondendo ao vivo, questões formuladas via fax e canal de voz. Essa interatividade não se limita, entretanto, ao momento da emissão. Os telealunos podem, no decorrer do curso, enviar fax e corresponderse com os especialistas para formular questões, sugerir debates, tirar dúvidas. Na sua parte final, os programas incluem sugestões sobre atividades que os professores podem desenvolver em sala de aula, tendo como referencial as discussões teóricas transmitidas.

A recepção, por sua vez, se faz de modo organizado, em telepostos geralmente localizados em escolas, com a presença permanente do orientador de aprendizagem, o qual dinamiza e orienta as atividades dirigidas aos cursistas, exercendo a mediação pedagógica, o 
acompanhamento e controle, propiciando também a avaliação. Diferencia-se de outros programas de educação a distância que prevêem modalidades de recepção menos controladas.

O programa compõe-se de módulos, entre os quais o denominado Série do Ensino Fundamental constitui o de formação mais abrangente. A cada nova Série são introduzidas modificações, seja no conteúdo, seja na forma de apresentação. Sua transmissão atualmente dura em média três meses consecutivos, embora já tenha tido quatro meses de duração. Há ainda módulos mais específicos, que abordam temas variados, quais sejam: Literatura Infantil, Educação Sexual, Educação Física, Educação Especial, Educação de Jovens e Adultos, Alfabetização, Saúde, AIDS e Drogas, Salto Férias. Esses módulos têm sido emitidos em diferentes momentos ao longo das programações anuais.

Já em 1992, 25 dos 26 estados e o Distrito Federal iniciaram a sua participação na emissão monitorada do programa, sendo que Tocantins a ele se integrou no ano seguinte. A Tabela I mostra a cobertura e a evolução das inscrições na Série do Ensino Fundamental no país.

TABELA I

PROGRAMA “UM SALTO PARA O FUTURO" - SÉRIE ENSINO FUNDAMENTAL NÚMERO DE CURSISTAS E DE TELEPOSTOS SEGUNDO O ANO E A UNIDADE DA FEDERAÇÃO

\begin{tabular}{|c|c|c|c|c|}
\multirow{2}{*}{ ANO } & N. DA SÉRIE & CURSISTAS & TELEPOSTOS & TELESSALAS \\
\hline \multirow{2}{*}{1992} & $\mathrm{I} *$ & 13357 & 433 & 600 \\
& $\mathrm{II}^{*}$ & 16361 & 564 & 724 \\
\hline \multirow{2}{*}{1993} & $\mathrm{III}^{*}$ & 30114 & 782 & 895 \\
& $\mathrm{IV}^{*}$ & 35070 & 914 & 1373 \\
\hline \multirow{2}{*}{1994} & $\mathrm{~V}^{*}$ & 52248 & 1467 & 1921 \\
& $\mathrm{VI}^{*}$ & 50459 & 1542 & 2024 \\
\hline \multirow{2}{*}{1995} & $\mathrm{VII}^{*}$ & 44528 & 1435 & 1846 \\
& $\mathrm{VIII}$ & 42046 & 1444 & 1708 \\
\hline \multirow{2}{*}{1996} & $\mathrm{IX} * *$ & 39891 & 1459 & 1698 \\
& $\mathrm{X}^{* * *}$ & 43525 & 1501 & 1686 \\
\hline
\end{tabular}

Fontes: *Fundação Roquette-Pinto. Programa Um Salto para o Futuro. Quadro demonstrativo, s/d.

**TVE; Presidência da República; Secretaria de Comunicação Social; Fundação Roquette-Pinto; Departamento de Tecnologia Educacional. Relatório de Avaliação - Série IX/I996, s/d.

**** TVE; Presidência da República; Secretaria de Comunicação Social; Fundação Roquette-Pinto; Departamento de Tecnologia Educacional. Relatório de Avaliação - Série X, s/d.

No decorrer dos anos, a audiência do programa ampliou-se significativamente, verificando-se uma curva ascendente de inscritos na Série do Ensino Fundamental, que atinge o pico em 1994, passando a declinar um pouco desde então. Em 1996, havia arrolados 83.416 cursistas.

Até 1996 "Um Salto para o Futuro" foi transmitido diariamente via satélite para todo o território nacional, das 19 às 20 horas, pela TVE do Rio de Janeiro e demais emissoras de televisão educativa, pela rede Brasil. Com a sua transferência nesse ano para a Secretaria de Comunicação Social da Presidência da República, a Fundação Roquette-Pinto continuou produzindo o programa, mas teve de redefinir suas estratégias de emissão e recepção. Embora 
não seja mais produzido no âmbito do Ministério - "Um Salto para o Futuro" foi incorporado à programação da TV Escola -, continua sendo transmitido ao vivo no mesmo horário, entretanto, por meio de canal fechado, o que contribuiu para limitar a sua audiência. No dia seguinte, a TV Educativa reprisa o Programa pela manhã em canal aberto.

O acompanhamento sistemático, efetuado por um sistema de monitoria e avaliações externas realizadas por instituições de pesquisa a pedido do MEC, da Fundação RoquettePinto, ou ainda dos estados encarregados da sua implementação, tem sido um recurso utilizado para testar a validade do Programa ou obter o seu aperfeiçoamento.

\section{AS AVALIAÇÕES EXTERNAS DO PROGRAMA E SEUS PROPÓSITOS}

Em 1992, a Fundação Carlos Chagas realizou uma avaliação externa da Série I do Ensino Fundamental, considerando os programas de TV, seu conteúdo, forma e emissão, bem como os materiais impressos de apoio. $\bigcirc$ estudo teve então como focos de análise os especialistas, os agentes educacionais envolvidos, os cursistas e o processo de implementação. Além da análise do programa realizada por assessores especialistas, foram feitas visitas a 28 telepostos, observações em dezoito telessalas e aplicados opinionários e exercícios de verificação de aprendizagem em 604 telealunos. A amostra abrangeu oito estados brasileiros, distribuídos pelas cinco regiões do país, sendo que na maior parte deles o percentual de telessalas e de cursistas contemplados esteve bem acima de 10\%, o que proporcionou boa margem de segurança à interpretação dos dados (Fundação, 1993). Artigo refletindo sobre os resultados desse trabalho foi publicado por Barretto (1997).

Em 1997, nova avaliação externa da Série, na sua versão XI, foi realizada pela mesma instituição, em pesquisa de menor âmbito na qual participaram três estados de diferentes regiões, escolhidos sob o critério regional, a saber: Ceará, Minas Gerais e Santa Catarina. Neste último estudo, além das dimensões analisadas anteriormente, o propósito foi o de averiguar, em caráter piloto, possíveis impactos da formação do docente em serviço na prática de sala de aula.

Agentes educacionais dos estados e municípios foram entrevistados e documentos sobre a implementação do Programa examinados, tendo em vista a apreensão da pluralidade de condições em que ele é transmitido. Vídeos e material de apoio foram analisados por especialistas das diferentes áreas do conhecimento escolar. ${ }^{2}$ Com base nesse material, foram propostos exercícios de verificação dos conteúdos e orientações metodológicas a uma amostra de cem cursistas dos três estados, freqüentando telepostos das capitais ou de algumas cidades

2. As áreas do conhecimento foram analisadas pelos seguintes assessores: Língua Portuguesa: Maria Thereza Fraga Rocco; Matemática: Manoel Oriosvaldo de Moura; Estudos Sociais: Kátia Abud e Elba Siqueira de Sá Barretto; Ciências: Regina Cândida Elero Gualtieri; Arte: Maria Felisminda Rezende de Fusari e Maria Heloísa Corrêa de Toledo Ferraz. 
do interior: Palmácia, no Ceará; Sete Lagoas, em Minas Gerais e Itajaí, em Santa Catarina. Concomitantemente foram selecionadas quatro classes do ensino fundamental cujas professoras haviam assistido à Série XI. Nessas classes, foram recolhidos materiais produzidos pelas crianças em situações rotineiras de sala de aula durante o primeiro semestre, entrevistadas as professoras e feitas observações de aulas durante um curto período de tempo, com vistas a lograr uma contextualização, por mínima que fosse, das atividades desenvolvidas com os alunos. Os mesmos especialistas procederam também à análise dos exercícios de verificação de aprendizagem realizados pelos cursistas e das atividades registradas pelos alunos do ensino fundamental (Fundação, 1997).

É com base nessas duas avaliações que faremos as reflexões sobre o Programa, detendo-nos mais detalhadamente na segunda por ser a mais recente e menos divulgada. Essas reflexões guiaram-se sobretudo pelo intuito de destacar aspectos fundamentais do modelo de ensino a distância desenvolvido pelo Programa, tendo em conta o fato de que a sua concepção e o teste de realidade por que passou têm muito a acrescentar à experiência nacional sobre o assunto.

Sem condições de maior aprofundamento no universo cultural dos docentes, o que demandaria um outro tipo de estudo, as pesquisas realizadas revelaram, contudo, uma preocupação com o receptor numa dimensão mais abrangente do que as avaliações que contemplam apenas a opinião, as críticas e as sugestões dos cursistas sobre o Programa. Procuram apreender, em certa medida, o grau de decodificação, a leitura que o cursista efetua dos conteúdos e metodologias veiculados, tentando, sempre que possível, evitar a simples ênfase na mera reprodução da versão prescrita.

Quanto à apreciação da prática docente e suas eventuais mudanças associadas à participação no Programa, na impossibilidade de permanecer por um tempo razoável nas salas de aula dos cursistas em 1997, restou-nos o esforço de cotejar o seu discurso sobre o Programa e sobre a sua própria prática com alguns indícios da atuação efetiva em sala de aula.

\section{QUESTÕES DE IMPLEMENTAÇÃO}

\section{A ação compartilhada entre as instâncias}

Uma das características inovadoras do Programa é a ação compartilhada no nível das diferentes instâncias federativas. Embora esta não seja a primeira experiência de programa educativo via satélite, trata-se da primeira experiência realizada em âmbito nacional e dentro de uma perspectiva articulada de colaboração entre a União, estados e municípios. Um outro aspecto que chama a atenção, no caso, é o envolvimento do próprio Ministério da Educação com ações de caráter propriamente educativo no desempenho de suas funções de apoio ao ensino fundamental, mormente quando se considera que esse órgão durante muitos anos dirigiu o grosso de seus esforços a programas de apoio à infra-estrutura das redes escolares ou a programas de caráter compensatório, como o da merenda escolar. 
No caso de "Um Salto para o Futuro", enquanto cabe ao governo federal coordenar a política de capacitação, produzir o Programa, garantir a sua emissão por todo o país e implantar um sistema de acompanhamento que lhe dê suporte, são os estados que se responsabilizam pela implantação e implementação da sua estrutura organizacional, bem como pela certificação dos cursistas. As Secretarias Estaduais de Educação se responsabilizam pela divulgação do Programa e pela montagem da infra-estrutura requerida para o funcionamento das telessalas, incluindo o provimento de pessoal, ou seja, de orientadores de aprendizagem e supervisores, e também dos profissionais encarregados da parte administrativa e técnico-operacional.

Para tanto, as unidades federadas devem alocar recursos próprios em seu orçamento anual, condição necessária para que recebam assistência técnica ou financeira ${ }^{3}$ da União. Essa exigência é importante, não só porque cria condições de viabilização do Programa, como também de sua inserção no conjunto das atividades desenvolvidas pelas administrações junto aos seus docentes. Considerando, porém, que os orçamentos das Secretarias Estaduais de Educação estão quase integralmente comprometidos com o pagamento de pessoal, o percentual de recursos destinados à melhoria do ensino e capacitação docente costuma ser muito pequeno, sendo que o Programa deve disputar o financiamento com outras iniciativas porventura existentes no estado, o que certamente impõe claros limites à sua expansão por essa via.

Os municípios também podem ou devem ser envolvidos na implementação do Programa, mas ainda constituem o elo mais fraco da atuação compartilhada. Sua participação é definida no âmbito das relações com a Secretaria de Educação do Estado, compondo um quadro heterogêneo nas regiões pesquisadas. A adesão dos municípios costuma ser espontânea, embora se exija, em alguns estados pelo menos, que as telessalas aí sediadas tenham um número mínimo de cursistas e se situem em locais de fácil acesso. As administrações locais ordinariamente costumam prover ajuda para a reprodução dos materiais, providenciar equipamentos, oferecer auxílio-transporte e alimentação aos cursistas.

A interação que se estabelece entre a rede estadual e os municípios passa por acordos que, de modo geral, ficam por conta do interesse dos dirigentes ou da conjuntura política local, o que pode favorecer a disseminação do Programa com características clientelistas ou aumentar os riscos de continuidade na programação. $\bigcirc$ envolvimento das administrações locais tem, freqüentemente, se restringido à indicação dos locais de maior demanda, à cessão do espaço físico e de algum apoio logístico ao funcionamento dos telepostos. Devido às articulações mais profundas entre as redes municipais e estaduais de ensino, que se estariam criando por conta das novas formas de financiamento do ensino fundamental e da intensificação do regime de colaboração entre as instâncias, é possível que haja mudanças apontando

3. No início da implantação do Programa o MEC ofereceu pequena complementação financeira a certos estados para cobrir gastos com a implementação; entretanto, na ocasião do estudo de 1997, não se teve notícia de nenhum aporte da União para tais despesas. 
para a maior participação das redes municipais em alguns estados. Entretanto, no último estudo realizado não foi possível detectá-las com clareza.

Em 1996, com a transferência da Fundação Roquette-Pinto para a Secretaria de Comunicação Social da Presidência da República, fragiliza-se o suporte requerido para a produção e disseminação do Programa e debilitam-se os mecanismos requeridos para coordená-lo e articulá-lo diante do retraimento do Ministério da Educação. A linha direta estabelecida para a implementação da formação docente, mediante contato do MEC com as Secretarias de Educação dos diferentes estados, passa a ser assumida precariamente pela própria Fundação Roquette-Pinto, que não possui o peso político do Ministério nas relações com as Secretarias de Educação, nem tampouco a infra-estrutura necessária para o acompanhamento, apoio e controle das atividades desenvolvidas.

Deixando de ser um programa prioritário do MEC, visto que este órgão passa a ocupar-se mais intensamente da produção e disseminação da programação da TV Escola, a importância relativa de "Um Salto para o Futuro" diminui aos olhos da administração dos estados, sendo que sua manutenção começa a depender, muito mais do que em períodos anteriores, de um interesse específico das unidades federadas na sua continuidade.

Tendo em conta os três estados em que foi efetuada a pesquisa de 1997, observouse que a indefinição que precedeu a passagem das emissões para a TV a cabo e a ausência de uma articulação mais efetiva entre a esfera federal e as Secretarias Estaduais e Municipais a partir de então, chegaram a ocasionar problemas ou dificuldades operacionais. A dinâmica da implementação do Programa é significativamente afetada ao gerar ambigüidade na assunção de papéis e funções por parte das instâncias responsáveis por ela, o que acaba interferindo na oferta e no melhor aproveitamento das Séries de TV por parte dos cursistas.

\section{Estratégias diferenciadas de desenvolvimento da programação}

Considerando que uma característica das iniciativas de formação continuada de docentes tem sido a sua descontinuidade e a desarticulação em relação às ações com as quais as escolas estão envolvidas, uma mirada mais atenta ao modo como o Programa se insere efetivamente nas atividades desenvolvidas com os professores pelas Secretarias de Educação e à forma como ele é recebido pelos agentes educacionais e cursistas oferece um quadro muito diversificado do que acontece de estado para estado.

Em 1992, ${ }^{4}$ no Mato Grosso, observou-se um grande envolvimento da Secretaria de Educação com o Programa, e um esforço deliberado de incorporá-lo às demais atividades de capacitação docente. $\bigcirc$ estado mantinha então convênios com duas universidades brasileiras e programava um terceiro com uma teleuniversidade do Canadá, sendo que, nesse contexto, o Programa passava a ser um pré-requisito para que o professor pudesse realizar cursos de especialização previstos por tais convênios.

4. Em relação às estratégias de implementação do Programa, na pesquisa de 1992 , focalizamos apenas os estados de Mato Grosso, Acre e Ceará. 
Em Rio Branco, no Acre, a despeito das dificuldades de funcionamento, "Um Salto para o Futuro", representava, no início da década, a única oportunidade de reciclagem dos docentes da rede pública.

No outro extremo, encontra-se São Paulo que, pelo fato de contar com amplos programas institucionais de formação continuada de docentes, tem deixado sistematicamente de lado a possibilidade de montar uma infra-estrutura para a utilização regular do Programa.

Estado do Ceará opta por dirigir inicialmente o Programa às numerosas escolas comunitárias de Fortaleza, até então totalmente sem assistência, bem como por expandir a programação pelos municípios. No segundo semestre de 1992, foi campeão de audiência, respondendo por 37\% dos cursistas inscritos no país, tendo-se valido, para expandir-se, da infra-estrutura já montada nas localidades para a educação a distância.

Em 1997, constata-se ainda um comprometimento significativo do Ceará com "Um Salto para o Futuro", em um contexto político em que a escola, os municípios e a administração estadual foram chamados a redesenhar suas responsabilidades para com o ensino fundamental. Nesse caso, procura-se dar destaque aos parâmetros pedagógicos de uma educação de qualidade, valorizar o professor, oferecendo-lhe melhores salários e maiores oportunidades de capacitação, e avaliar os resultados dos alunos do ensino fundamental (Ceará, s/ d), sendo que o Programa amolda-se às atividades de formação continuada a serem incorporadas ao dia-a-dia da escola.

A despeito dessa postura positiva em relação ao Programa no Ceará, constata-se uma redução muito grande do número de inscritos no decorrer dos anos, tendo baixado de 6. 120 na Série I, em 1992, para 555 inscritos na Série XI, em 1997. O fato de que nesse estado, o Programa não esteja mais sendo exibido pela TV aberta, determina que ele somente seja captado no horário normal naqueles telepostos que dispõem de antena parabólica. Além disso, a emissão da Série do Ensino Fundamental durante vários anos consecutivos pode ter alcançado parte significativa do público-alvo, particularmente nos municípios pequenos, e estaria dando mostras de esgotamento da demanda por parte dos professores, pelo menos nessas localidades que se prepararam para a emissão monitorada do Programa. Essa conclusão é corroborada pelo fato de que as inscrições em outras séries oferecidas esporadicamente como "Educação Especial”, "Educação Infantil” e "Alfabetização", têm sido elevadas, indício de que as possibilidades de exploração de outros temas e abordagens continuam postas.

Em Santa Catarina, o Programa ultimamente concorre com outros projetos de educação a distância que vêm despertando maior interesse, como as teleconferências, por exemplo, e, nesse sentido, o público atingido tem sido pequeno, perfazendo um total de 480 inscritos em 1997. Outro indício da sua pequena receptividade é o empenho da Secretaria de Educação em produzir seu próprio programa de educação a distância, objetivando garantir uma formação docente mais articulada à proposta curricular do estado e mais afinada com as especificidades da região. 
Minas Gerais tem sido considerado pela Fundação Roquette-Pinto como um dos estados mais atuantes desde o início do Programa até os dias atuais, tanto pela participação da Secretaria Estadual de Educação, como das prefeituras. Suas inscrições, que atingiam setecentos telealunos em 1992, à época da exibição da Série XI, perfaziam 6.624 cursistas.

A propósito, a prévia divulgação de um cronograma das Séries a serem exibidas durante o ano é considerado essencial para que supervisores e orientadores de aprendizagem programem suas atividades. A época em que o Programa é veiculado pode influir na demanda. Quando a emissão ocorre no início do ano, a procura tende a ser menor, pois é o momento em que os professores ainda não escolheram as unidades escolares em que irão lecionar. Séries longas ou, ao contrário, muito curtas ou séries reprisadas, também, tenderiam a desestimular o cursista.

\section{Atuação dos agentes educacionais e apoio material}

O Programa baseia-se na recepção organizada, que supõe a presença de um orientador de aprendizagem em cada telessala. Este costuma ser um professor normalmente lotado em cargos técnicos de orientação pedagógica ou de supervisão nos sistemas estaduais de ensino, freqüentemente com formação de nível superior.

A qualificação dos agentes necessários à implementação do Programa é por vezes feita por cursos regulares promovidos pelas Secretarias de Educação, ou de encontros em que se avalia o funcionamento dos telepostos, suas dificuldades, inovações. O pressuposto é o de que, dada a sua qualificação escolar maior que a dos cursistas, eles dominem os conteúdos e orientações metodológicas disseminados pela programação.

No Ceará, onde a experiência do estado com a educação a distância desde 1974 parece ter contribuído decisivamente para a boa acolhida ao Programa, a Fundação de Teleducação do estado tem se responsabilizado pela metodologia implementada pela Secretaria de Educação e tem feito um investimento significativo na formação do orientador de aprendizagem. Ele é definido como o dinamizador responsável pela coordenação e por todo o trabalho na telessala, bem como pelo desenvolvimento dos conhecimentos, habilidades e atitudes necessários à sua dinâmica. Não obstante a atenção especial dada aos orientadores de aprendizagem no estado, vale registrar que indícios da sua atuação observada, a análise da proposta de capacitação e a quantidade de material que circula nos cursos sobre dinâmica de grupo sugerem que esses agentes estariam se ocupando sobretudo com tarefas motivadoras e de animação cultural, com vistas a manter o interesse da audiência e a promover atividades de integração, sem explorar mais profundamente os conteúdos propriamente ditos veiculados pelo curso.

Essa situação leva a inferir que a tradição herdada pelos cursos de formação de orientadores, em locais que têm experiência antiga em educação a distância, ainda não se teria libertado do pressuposto, dominante em décadas passadas, de que a tecnologia do ensino se basta a si mesma para provocar grandes mudanças na educação, cabendo aos 
agentes educacionais uma tarefa secundária em relação ao desenvolvimento da programação. Não obstante, acerca da concepção de que um bom curso e materiais de qualidade preparados pelos melhores especialistas terminariam por tornar supérfluos os educadores, constatou-se, conforme relembra Hawkins ( 1995), que os bons resultados obtidos nos moldes do ensino a distância costumam vir aliados à qualidade da monitoria prestada aos alunos, de sorte que não se trata de dispensar os agentes humanos, mas de apoiá-los na sua tarefa substantiva.

A atuação do agente educacional esvaziada de conteúdo parece, pois, não condizer com a própria filosofia do Programa, que prevê inclusive uma hora a mais de trabalho dos cursistas com o orientador de aprendizagem, além da emissão de TV. A questão subjacente ao seu trabalho é, portanto, a natureza de sua contribuição ao desenvolvimento de programas de tão amplo alcance. Será a mediação feita por ele suficiente para que propostas com um alto grau de generalidade tenham condições de ser decodificadas em termos das necessidades dos docentes das respectivas telessalas? A esse respeito, as avaliações realizadas não permitem qualquer generalização, dada a extensão do país e a diversidade de funcionamento do Programa nos estados. Contudo, em redes que dispõem de pessoal técnico mais qualificado, a probabilidade de haver uma contribuição mais rica desses agentes educacionais é maior, o que, em princípio, concorre para o sucesso do modelo em regiões ou localidades que possuem tais recursos humanos, ou seja, nas regiões em que as oportunidades de aquisição de conhecimento já são maiores.

Nos estados visitados, em 1997, foi constatada, por vezes, a falta de um monitoramento mais efetivo nas telessalas de alguns municípios, pois a necessidade de deslocamento dos técnicos nos horários noturnos vem comprometendo essa atividade, isso sem falar na carência de pessoal técnico-pedagógico para sustentar a infra-estrutura. Como há estados em que se exigem profissionais que sejam dos quadros da Secretaria de Educação, torna-se difícil motivá-los devido à maior carga de trabalho que terão de assumir. Todos esses percalços apontam para o grande esforço necessário por parte das unidades federadas para manter o Programa funcionando a contento.

Quanto à infra-estrutura material necessária ao funcionamento, as questões mais prementes dizem respeito à dificuldade de manutenção dos equipamentos necessários, à qualidade da recepção e à morosidade na remessa e distribuição dos materiais impressos. $\bigcirc$ material de apoio tem igualmente deixado a desejar devido à má qualidade das fotocópias. Nessa mesma linha, observou-se ainda que a má qualidade das gravações dos Programas tem impedido sua posterior utilização. Também, o ambiente físico e o aparato tecnológico nem sempre são adequados à recepção, seja pelo fato de os prédios serem impróprios para a instalação dos equipamentos necessários, seja pela disposição e arquitetura das salas que impedem uma recepção confortável, ou, ainda, pela falta de apoio básico como a existência de biblioteca, hemeroteca e de fotocopiadora. Além disso, nem sempre os telepostos possuem equipamentos adequados para a recepção via canal fechado, o que tem causado a procura daqueles nos quais a recepção é melhor. 
Sobre esses aspectos há de se convir, porém, que a programação variada e de duração relativamente curta, oferecida pelo Programa "Um Salto para o Futuro", não requer necessariamente a instalação de um suporte material permanente e oneroso de apoio ao funcionamento das telessalas, caso contrário criaria demandas adicionais de infra-estrutura que restringiriam sua flexibilidade para atingir novos grupos de professores em outras localidades.

\section{Cobertura e custos}

Essas questões suscitam a discussão de um outro aspecto que mereceria ser devidamente equacionado: a relação custo-benefício no Programa. Ainda que esse tipo de análise não constasse dos propósitos dos estudos realizados, em vários momentos da pesquisa o problema dos custos foi colocado, indicando que, certamente, dados mais precisos a respeito dos recursos necessários à efetivação de um programa nacional de tão grande porte poderiam ajudar a dimensionar melhor as políticas de educação a distância no país. Nesse sentido, vale lembrar que, dando cobertura à Conferência Mundial sobre Ensino Superior da Unesco, realizada em Paris, em outubro deste ano, Rossetti (1998) chama a atenção para o caráter oneroso dos programas de educação a distância — ao contrário do que afirmam seus defensores - ao mesmo tempo em que ressalta o seu reduzido grau de disseminação.

No caso brasileiro, a ação compartilhada entre as três instâncias de governo, numa perspectiva descentralizada, dificulta sobremaneira o cálculo do montante despendido. Destaque-se, a esse respeito, a preocupação explícita de certos estados com os custos ligados à implementação, visto que a transmissão monitorada, em grande parte sob seu encargo, requer, para expandir-se, um comprometimento crescente de recursos captados no próprio estado e nem sempre disponíveis nas redes públicas de ensino. Como também variam o número de municípios envolvidos e as suas formas de contribuição, o cálculo dos custos se torna ainda mais complexo.

O cômputo dessas despesas deverá ser cotejado evidentemente com a cobertura do Programa e o tipo de clientela atendido. Em 1992, o MEC havia estabelecido a reciclagem de 300 mil docentes como meta a ser alcançada no ano por essa via. Ora, considerando o total acumulado de cursistas inscritos na Série do Ensino Fundamental, até o final de 1996, em 26 estados, chega-se a pouco mais de 200 mil telealunos. Todavia, levando-se em conta o total de inscrições efetuadas no conjunto dos módulos oferecidos por "Um Salto para o Futuro", até o final do ano de 1995, obtém-se 500 mil telealunos atendidos num espaço de quatro anos. Se esse número está ainda longe de atingir o universo de professores das quatro séries iniciais, sobretudo se se considera que muitas das inscrições são feitas pelos mesmos sujeitos, que podem assistir a vários módulos do Programa, há de se convir que o total de docentes atingidos é muito representativo e que se está, de fato, diante de um poderoso veículo de formação de corações e mentes, a um custo que tem sido, até agora, de algum modo, compatível com a capacidade financeira de nossos sistemas de ensino. 
Os indícios de desarticulação do Programa, detectados no estudo de 1997, mostram, porém, além da queda nas inscrições, que seu público vem sofrendo alterações significativas. A pesquisa evidenciou que, nos três estados investigados no primeiro semestre, $48 \%$ dos cursistas que responderam aos exercícios eram alunos do curso de magistério e $61 \%$ deles não tinham experiência profissional, num sinal de que parcela importante do professorado das redes públicas estaduais e municipais, a clientela-alvo por excelência, não estaria mais sendo efetivamente alcançada ou atraída pelo Programa.

\section{MENSAGEM HOMOGENEIZADA, RECEPÇÃO DIFERENCIADA}

Se tomarmos como referência o balanço que faz Candau dos cursos de formação continuada (1996), o Programa, nos moldes como foi concebido, poderia se enquadrar entre aqueles que compõem o modelo clássico de formação de docentes, ainda que venha a utilizar as tecnologias mais avançadas de educação a distância. $\bigcirc$ pressuposto desses cursos seria, segundo a autora, uma concepção dicotômica de teoria e prática, em que a produção do conhecimento corresponde à universidade, ficando reservada aos professores do ensino básico a responsabilidade de fazer a sua transposição didática e de socializar o saber adquirido.

Um programa transmitido via satélite para todo o território nacional certamente veicula uma mensagem homogeneizadora que longe está de atender a certas questões postas pela ação específica das escolas, as quais traduzem as diferenças e peculiaridades dos sujeitos, das localidades e das regiões. "Um Salto para o Futuro" procura, porém, tangenciar problemas que são comuns aos professores, escolas e regiões brasileiras, buscando superar a concepção que centra a iniciativa da atividade de comunicação exclusivamente no emissor e espera que o receptor apenas reaja aos estímulos que lhe são enviados (Martín-Barbero, 1995). Nesse sentido, o Programa ensaia uma proposta interativa, visando o estabelecimento de um diálogo em que a expressão de outras vozes não seja apenas residual, mas passe a incorporar a própria feitura da programação.

A possibilidade de explorar a potencialidade de participação das televisões educativas dos estados, introduzindo complementações locais e regionais, que apresentem maior diversidade de linguagem e maior aproximação em relação à realidade vivida pelas escolas, foi bastante cogitada nos anos iniciais da programação e certamente contribuiria para enriquecêla. No entanto, agora parece estar cada vez mais distante de viabilizar-se.

Contudo, mais do que isso, a própria interlocução direta com os cursistas, concebida no formato original do Programa, apresenta enorme potencial comunicativo. Assim, grande importância tem sido atribuída à interatividade, tanto pelos telealunos quanto pelos técnicos e especialistas, e numerosas sugestões foram feitas, por ocasião da avaliação inicial do Programa e de outras, para explorar melhor essa característica inovadora.

Infelizmente, tais sugestões parecem não estar recebendo na atualidade maior apreço por parte dos produtores. É reduzida a participação dos cursistas nas Séries recentes e limita- 
da a troca de experiências com os especialistas, bem como falta naturalidade nas questões a estes formuladas pela audiência. A preparação prévia de um teleposto para ser focalizado pela produção tem criado situações artificiais de interatividade, dando margem a que autoridades locais ou pessoas de projeção aproveitem a oportunidade para expressar suas opiniões sobre temas educacionais, o que vem limitar as participações dos próprios cursistas durante as emissões.

Outro problema tem sido a ausência de um retorno sistemático às questões formuladas pelos cursistas. Esse retorno, com a realização de programas específicos ou publicação de boletins especiais com respostas às questões mais significativas formuladas pelos cursistas, poderia aproximar a programação das demandas efetivas dos professores. A atuação dos especialistas nas emissões televisivas, por sua vez, ainda que considerada bastante competente quanto ao domínio dos conteúdos, deixa em várias ocasiões, de aprofundar a discussão sobre aspectos metodológicos importantes, de articular os temas enunciados com as atividades didáticas, ou ainda, de responder a perguntas formuladas pelos cursistas.

Independentemente das razões ou dificuldades enfrentadas pelos produtores do Programa, o fato é que se constata uma certa pobreza em relação aos procedimentos utilizados em outras Séries, quando era mais presente a preocupação de encontrar formas de interlocução capazes de levar os professores a se reconhecerem como sujeitos do processo de reconstrução de saberes.

No que tange aos recursos tecnológicos necessários à interatividade, registrou-se um número insuficiente ou um funcionamento precário dos aparelhos de fax, telefone e canal de vídeo para que os cursistas tivessem sua participação ampliada, levando a crer que, uma vez tendo deixado de estar na mira dos dirigentes, o suporte necessário a programas desse tipo tende a tornar-se cada vez mais insuficiente.

A fim de que a troca entre a audiência e especialistas possa tornar-se mais efetiva, espontânea e contemplar um maior número de cursistas, seria, portanto, necessário o redimensionamento do processo interativo, dada a importância e as potencialidades que apresenta.

Outro aspecto que merece ser discutido é que o Programa, ao trabalhar com cursistas que se inscrevem voluntariamente para freqüentá-lo, possui uma audiência, em princípio, originária de diferentes estabelecimentos de ensino. Desse modo, ele não influencia diretamente a dinâmica da escola, uma vez que o professor isolado, ainda que sensibilizado pelas mudanças propostas no curso, não encontra, via de regra, um ambiente propício à discussão e à adoção de inovações ao retornar ao seu ambiente de trabalho.

As novas descobertas sobre a formação continuada de professores, ao contrário, postulam que a escola deve ser o seu locus privilegiado. De acordo com Antônio Nóvoa, citado por Candau (1996), experiências articuladas ao desempenho profissional do docente têm procurado estimular os componentes formativos que mostrem estreita relação com o cotidiano escolar e permitam trabalhar com o conjunto dos professores da escola, de modo 
a favorecer a reflexão e as práticas coletivas e solidárias de intervenção pedagógica, tendo como eixo os problemas e projetos de ação e não os conteúdos acadêmicos.

Em países com as dimensões continentais como o nosso e com as insuficiências generalizadas de formação do magistério, há, contudo, de se ponderar que as políticas de formação continuada não poderão ficar apenas à mercê das iniciativas das próprias escolas, sendo necessário encontrar alternativas que conciliem a necessidade de envolvimento do conjunto dos atores da unidade escolar com a oferta de oportunidades de formação dirigidas a um público-alvo muito maior.

Essa dificuldade de mobilizar o conjunto dos profissionais da escola tem sido em parte contornada pelas oportunidades criadas para que os professores cursistas discutam com os pares e orientador de aprendizagem as tentativas que fazem de introduzir as propostas veiculadas no curso, em suas próprias salas de aula. Isso já havia sido constatado, especialmente na avaliação de 1992, ocasião em que os telepostos eram freqüentados, na sua maioria, por docentes em exercício. Havia então uma intensa troca de experiências entre os cursistas-professores, o que sugere a possibilidade de valorização do saber docente e de apoio às iniciativas de mudança nas práticas escolares, estimuladas pelos conhecimentos e orientações recebidos, intensificando a interlocução entre o saber profissional e o saber acadêmico.

Durante a emissão da Série XI, predominaram, porém, nas telessalas pesquisadas, alunos dos cursos de magistério e outros que não eram regentes de classe. Certamente, esse fato pode ter contribuído para diminuir a possibilidade de compartilhar as experiências em sala de aula durante o telecurso e de submetê-las a uma discussão coletiva, que, sem dúvida, poderia enriquecê-las e levar os professores a explorarem novas práticas e a refletirem sobre elas.

Alguns estados e municípios já têm explorado a possibilidade de gravar o Programa em vídeos e de exibi-lo posteriormente na escola, envolvendo um grande número de agentes educativos da unidade, tal como na proposta da TV Escola. Atualmente, se, de um lado, a alteração das formas de transmissão do Programa vêm trazendo certas dificuldades operacionais, de outro, com a antena parabólica transmitindo adequadamente o Programa em cada escola, cria-se, em princípio, a possibilidade de que ele seja assistido por um grupo maior de professores e técnicos da mesma unidade escolar. Uma indagação pertinente, nesse caso, seria a respeito do tipo de interação capaz de se estabelecer entre as atividades de formação contínua cultivadas pela escola — no exercício de sua autonomia — , e as orientações pedagógicas veiculadas no âmbito das redes escolares às quais tais escolas pertencem.

Particularmente interessante seria explorar, nessas condições, módulos que se propõem a demonstrar as potencialidades de um trabalho baseado numa perspectiva integradora e interdisciplinar do currículo, como a Série do Ensino Fundamental ora analisada, os quais poderão obter melhores resultados se contarem com a presença de coordenadores pedagógicos, supervisores, diretores e professores de diferentes componentes curriculares. 


\section{AS NOVAS PAUTAS EDUCACIONAIS DO PROGRAMA}

\section{Buscando superar a fragmentação do currículo}

O Programa não se propõe a dar conta de uma proposta acabada de currículo para as séries iniciais, conforme assinalado em artigo anterior (Barretto, 1997). O que ele procurou fazer, desde o seu início, foi propor a organização, na Série do Ensino Fundamental, de certos conteúdos a serem desenvolvidos com as crianças e suas respectivas abordagens em torno de alguns princípios integradores, de modo a evitar a excessiva fragmentação que costuma informar o currículo tradicionalmente estruturado em torno das disciplinas escolares.

As primeiras séries adotaram a alternativa de ordenação dos programas a partir de núcleos conceituais, ou seja, mediante a identificação de conceitos que, por perpassarem diversas áreas do conhecimento, tais como tempo, espaço, atividades humanas e linguagens, são considerados nucleares. A experiência de trabalho com esses conceitos, também chamados estruturantes, tem sido cultivada nas propostas curriculares do Rio de Janeiro por diferentes gestões das redes de ensino e pode encontrar fundamento no próprio Piaget que, ao se referir a conceitos de natureza transdisciplinar como esses, menciona o seu potencial formativo, uma vez que eles estariam contribuindo para a constituição dos esquemas operatórios fundamentais à aprendizagem.

trabalho em torno dos núcleos conceituais, a despeito de ter sido anunciado nos boletins iniciais da Série do Ensino Fundamental, não foi claramente explicitado no decorrer das emissões e no material de apoio. Pela sua complexidade, entretanto, ele demandava uma meta-reflexão que não foi feita com os cursistas, de sorte que estes não tiveram condições de apreender esse princípio ordenador da programação.

A Série do Ensino Fundamental sofreu várias alterações, inclusive no que toca à proposta pedagógica, e, embora não abandonando o propósito de oferecer aos professores indicações de como integrar os conteúdos curriculares, procurou chegar a formulações mais acessíveis aos docentes, estruturando os programas mediante três tipos de abordagem. A disciplinar, que aprofunda o conjunto de conhecimentos próprios de um dado campo do saber; a integradora, que se configura em propostas de tratamento de tópicos comuns a mais de uma disciplina ou área, e a multidisciplinar, que aborda temas ou questões mais gerais que permeiam os conceitos utilizados em diferentes campos do conhecimento. Entre esses últimos temas, que passeiam pelas reflexões de Ítalo Calvino, Humberto Eco, Foucault e outros autores de diferentes campos teóricos, figuram a consistência e exatidão, a importância da imaginação e da leveza, a identidade, a pluralidade de idéias e a provisoriedade do conhecimento, bem como outros, de ordem metodológica, como a importância de se envolver os alunos nas discussões, problematizar situações, valorizar o processo de resolução de problemas, mostrar os diferentes caminhos que levam a uma resposta. 
O esforço do Programa para concretizar propostas integradoras que demonstrem outras possibilidades de trabalhar em sala de aula, evitando a segmentação da abordagem e abrindo a possibilidade de tratar certos temas a partir de referenciais mais abrangentes do que o propiciado pelo recorte disciplinar, condiz com as tendências contemporâneas de tratamento do conhecimento dito escolar. Além disso, conforme aponta Lenoir ( 1997), para que possa ocorrer a passagem de uma prática tradicional para uma interdisciplinar e para que os professores passem a adotar objetivos integradores, uma das condições essenciais é que haja mudanças nas práticas de formação docente. Se se pretende que os professores trabalhem numa perspectiva interdisciplinar é preciso que os cursos em que são formados também adotem essa perspectiva. São as experiências efetivamente vivenciadas pelos professores, em momentos da sua formação ou de seu desempenho profissional, aquelas que eles tendem a reproduzir na prática docente.

Assim sendo, essa tentativa é inovadora, porquanto explora novos caminhos e tenta superar tanto a concepção que, como diria Lenoir ( 1997), atribui aos atores um imobilismo que seria proveniente de sua inserção em um sistema escolar regido por uma dinâmica inalterável, bem como a que leva em conta apenas os constrangimentos estruturais externos negando toda a possibilidade de autodeterminação do meio escolar.

Não obstante os méritos da intenção integradora, as críticas feitas aos programas integradores e sobretudo aos multidisciplinares por parte de cursitas e agentes educacionais, evidenciam a dificuldade de o professor trabalhar a partir dos enfoques ou da maneira como foram propostos. Alguns cursistas afirmaram, por exemplo, sentir certo desconforto ao serem chamados a transitar por referenciais teóricos bastante sofisticados, por temas contemporâneos que permaneciam, porém, pouco articulados dentro da estrutura do Programa. A referência constante a autores desconhecidos nos boletins, também foi citada como uma questão que dificultava a compreensão sobre as idéias por eles veiculadas.

Outras críticas, que incluem também as dos especialistas que examinaram os materiais, referem-se ainda à complexidade da linguagem dos boletins e da bibliografia citada; referemse a um certo descompasso existente entre materiais impressos e emissão de imagens, seja porque estas banalizam ou simplificam em demasia as idéias dos boletins, seja porque não estão de acordo com os pressupostos que os orientam. Há vídeos que nem sempre veiculam a mensagem que se quer transmitir, ou não ilustram o tema abordado; também há contradição entre os enunciados de uma abordagem que se pretende interdisciplinar e a apresentação de conhecimentos disciplinares de modo fragmentado e descontextualizado; ou ainda, incoerência nas atividades sugeridas para o trabalho em sala de aula em relação à metodologia preconizada. Ainda, do ponto de vista pedagógico, nem sempre as atividades propostas nos programas são passíveis de serem aplicadas na prática, devido às condições físicas e organizacionais das escolas públicas.

Em resumo, a ausência de uma conexão maior entre o que está proposto teoricamente nos materiais impressos e nas emissões, pode demonstrar a tensão existente entre 
linguagens provenientes de diferentes campos profissionais, como o da educação e o da mídia. Mas o conjunto da programação, mais do que isso, pode indicar a dificuldade de realizar uma proposta interdisciplinar no nível mesmo da produção, mostrando que o terreno é complexo e ainda muito pouco pamilhado por todos aqueles preocupados com a questão.

\section{Atualidade e adequação de conteúdos e abordagens}

As apreciações sobre o conteúdo e abordagem das diferentes áreas do conhecimento escolar foram feitas por especialistas durante as duas avaliações referidas, sendo que, na primeira delas, também foram consideradas as opiniões de cursistas e técnicos sobre cada área. Em 1997, a análise restringiu-se às opiniões dos especialistas das áreas; os telealunos e agentes educacionais fizeram apenas uma apreciação geral do Programa.

Os especialistas concordam que, via de regra, os conteúdos das Séries do Ensino Fundamental estão em consonância com a produção contemporânea dos respectivos campos do conhecimento e expressam freqüentemente as tendências mais avançadas em vários deles. Temas e conceitos tratados nos programas são, na maior parte das vezes, abrangentes e abordados de modo pertinente, embora em algumas áreas ou em questões pontuais haja restrições a determinados conteúdos ou à metodologia proposta.

No caso da Série XI, na qual nos deteremos mais, foram levados em conta não só os programas disciplinares, como também os integradores e multidisciplinares.

Em Língua Portuguesa, o tratamento teórico-metodológico dos temas dá ênfase ao fato de que falar e escrever na escola não podem estar divorciados dos usos reais e sociais da oralidade e da escrita. Reitera ainda a necessidade de o professor trabalhar com a dimensão dialógica do verbal, contemplando as variantes e diferentes registros lingüísticos. Dessa forma, evidencia-se pelo exame dos boletins e emissões, que ler não é ato solitário, constituindo-se em processo interativo que deve ser prioridade em todas as disciplinas. O Programa ressalta também que a leitura de diferentes modalidades de texto possibilita a produção lingüística, pois os mecanismos de produção verbal dos alunos dependem das diferentes interlocuções e interações.

Apesar da linguagem sofisticada impressa no material de apoio, a emissão consegue compatibilizar o texto dos boletins e as cenas gravadas em vídeos, sendo que os conceitos são permanentemente resgatados pelo apresentador e debatedores, além de ilustrados competentemente por inserções das mais variadas naturezas.

Em Matemática, os fundamentos teóricos do Programa privilegiam dois enfoques para o seu ensino: a resolução de problemas e a matemática como cultura, ambos considerados fundamentais para a contribuição da educação matemática à formação da cidadania. Os programas abordam a alfabetização como uma impregnação cultural de língua materna e linguagem matemática; mostram as diferentes técnicas de contagem e de cálculo ainda hoje usadas pela humanidade. Utilizam-se ainda de conhecimentos do cotidiano da criança para 
fundamentar a resolução de problemas e a construção de conceitos geométricos. No entanto, a utilização pedagógica da história da disciplina permanece ainda muito tímida, consideradas a sua importância para a formação do pensamento matemático e as possibilidades que oferece para a resolução de problemas.

Os boletins e as cenas gravadas nas emissões dos programas também sugerem a leitura da realidade sociocultural com o auxílio de ferramentas matemáticas como gráficos de índice de emprego, de inflação, de preço de bens de consumo e outros temas, que possibilitam uma abordagem interdisciplinar promovendo a integração com os esportes, a reprodução e recriação da variedade de formas da natureza, a organização e classificação de acervos, medições nas diferentes disciplinas. Permitem também relacionar a matemática com conhecimentos construídos nas diferentes profissões artesanais, como modelagem em argila, corte e costura, vidraçaria, marcenaria e outras.

Observa-se, no entanto, uma certa incoerência teórico-metodológica entre a proposta e a sua exemplificação. Ao mesmo tempo em que as emissões mostram uma abordagem de ensino que se contrapõe nitidamente à informação diretiva e à repetição mecânica dos conteúdos, refutando o caráter mecanicista das práticas tradicionais de sala de aula, as atividades propostas no bloco denominado "Engenhoca" mostram um modelo radicalmente oposto, exibindo atividades que sugerem um espontaneísmo no ensino dos conceitos matemáticos, em que o professor, como orientador, está ausente.

Os programas de Estudos Sociais iniciam por uma questão controvertida: a de constituir uma área-núcleo, capaz de integrar conteúdos das diversas Ciências Sociais, propondose, entretanto, a manter os campos das diferentes disciplinas como autônomos, a fim de que não se empobreça o seu tratamento. Explorando pequenos textos, os autores pretendem demonstrar a possibilidade de integração em torno dos Estudos Sociais. Os elementos enfatizados são conceitos e personagens que permeiam todas as ciências humanas. Destacados do contexto, entretanto, perdem seu significado teórico.

A programação procura também contemplar as diferentes dimensões da cidadania na perspectiva de uma sociedade que pretende garantir o direito de todos sob diferentes aspectos, ainda que muitas vezes não recorra a formulações claramente explícitas sobre o tema, ou não as desenvolva com profundidade. O tratamento clássico dado à questão da cidadania, que a associa tão somente ao exercício dos direitos civis e políticos, e que está mais presente nos livros didáticos, tende a ser revisto, buscando-se recuperar e valorizar a organização da população com vistas ao acesso aos bens sociais. Os movimentos sociais e demais formas pelas quais a população se organiza para reivindicar seus direitos e encaminhar soluções para os problemas que enfrenta, são considerados como exercício da cidadania.

A abordagem histórica, ao optar pela "história dos vencidos", tende a provocar uma simplificação do processo histórico, dando, por vezes, margem a uma visão maniqueísta. Os aportes da Sociologia mantêm, contudo, uma sustentação teórica mais sólida e colocam em 
pauta temas emergentes do currículo como o respeito às diferenças étnicas e de gênero e o pluralismo cultural.

Várias indicações referentes ao trabalho pedagógico enfatizam técnicas em detrimento da metodologia de ensino; são desvinculadas de conteúdos específicos da área e priorizam o "ensinar a fazer", com pouca atenção ao aspecto do "por que fazer".

Nos programas de Ciências, a concepção de saúde vai além da sua dimensão biológica, na medida em que é identificada com a qualidade de vida e concebida como um direito do cidadão. Na exploração da matéria e energia, assim como na abordagem da origem, diversidade e evolução da vida, priorizam-se as explicações de caráter teórico, a despeito da presença, nos boletins, de questões que poderiam estimular discussões sobre fenômenos observáveis por todas as pessoas e relacionados às definições dadas. Constatou-se ainda, na emissão, a presença de muitas afirmações questionáveis do ponto de vista teórico.

Em Arte os programas abordam aspectos importantes das atividades pedagógicas em Música, Artes Visuais/Plásticas e Teatro. As imagens e sons televisivos acompanham tal itinerário mostrando artistas e obras de diversas localidades, períodos, movimentos e culturas. Com isso, as emissões e boletins procuram dar conta das atuais tendências do ensino na área que preconizam a introdução de estudos sobre a História da Arte desde as séries iniciais, mostrando aos cursistas as possibilidades de integrar habilidades e conhecimentos imprescindíveis à formação dos alunos.

Percebe-se, ainda, nos programas específicos de Arte, uma preocupação em evidenciar a percepção de categorias estéticas que se apresentam em inúmeras situações cotidianas e nas manifestações artísticas, indicando que essa percepção deve ser investigativa e valorizar a atitude de descobrir e desvelar formas, conteúdos e significações. Os programas, porém, abordam mais o aspecto da produção expressiva das crianças e dos artistas nas modalidades mencionadas e tratam com menor intensidade dos aspectos referentes à aprendizagem de como apreciar a arte. A reduzida ênfase na análise da produção das diversas modalidades artísticas, torna difícil a compreensão da trama histórico-cultural e estética da humanidade.

\section{Apreciação geral do Programa}

Segundo os atores envolvidos, técnicos e cursistas de modo geral, o Programa "Um Salto para o Futuro" vem obtendo resultados positivos nos estados pesquisados. Depoimentos relativos à avaliação realizada em 1997 afirmam que há, sem dúvida, um crescimento profissional, pedagógico e teórico dos professores que freqüentam o curso.

Nesse sentido, foram citados o amadurecimento do seu senso crítico, a aquisição de conhecimentos específicos nas diversas áreas do currículo, o aprofundamento teórico e metodológico. Isso, sem falar na possibilidade de uma troca de experiências bastante proveitosa com os colegas, bem como na ampliação de seus horizontes profissionais. $\bigcirc$ reflexo desses fatores estaria se fazendo sentir não só pelo aumento de consciência do seu papel 
profissional e social, mas também no interior da própria sala de aula. No Estado do Ceará, por exemplo, os técnicos afirmam haver constatado uma melhoria nos índices de aproveitamento dos alunos das séries iniciais.

O Programa vem ainda repercutindo de maneira positiva no meio educacional e também em outras instâncias da sociedade, haja vista as constantes solicitações dos materiais veiculados (boletins e vídeos) por parte de escolas, universidades e outras instituições para fins de debate e orientação. Outro indício dessa repercussão positiva é a valorização dos professores da rede privada que cursaram as séries.

Além disso, a julgar pela avaliação positiva por parte de muitos cursistas, pelo seu empenho e envolvimento nas discussões, bem como pela solicitação de que sejam produzidas séries destinadas a outros níveis de ensino, pode-se dizer que "Um Salto para o Futuro" vem alcançando resultados promissores.

Tendo em conta a análise dos especialistas e a opinião dos agentes educacionais cursistas, técnicos e supervisores - é possível afirmar que, de modo geral, o conjunto de Programas da Série do Ensino Fundamental XI foi avaliado positivamente, especialmente quanto à sua estrutura, dinâmica, duração dos blocos e das emissões, desenvolvimento dos temas, uso de textos de apoio, ou seja, como modelo ou proposta de formação continuada de docentes a ser preservada. As críticas referem-se a aspectos que merecem ser redimensionados, tendo em vista o atendimento das reais necessidades da clientela usuária.

Pode-se ainda acrescentar que o Programa também tende a demonstrar a repetição de problemas existentes nos cursos de capacitação face a face, quais sejam, os de um equacionamento insatisfatório das relações entre o discurso propalado e o que é efetivamente realizado no próprio curso, reproduzindo os vícios dos centros produtores de conhecimento.

\section{A APRENDIZAGEM DOS CONTEÚDOS E ORIENTAÇÕES METODOLÓGICAS}

Tanto em 1992 como em 1997, foram propostas questões ou exercícios aos cursistas, visando aquilatar a sua capacidade de apreender os conceitos e metodologias veiculados e de aplicá-los em situações de sala de aula.

$\mathrm{Na}$ avaliação inicial, verificou-se que muitos conceitos importantes foram razoavelmente bem apreendidos pela maior parte dos cursistas no plano da verbalização. Mesmo no caso de respostas à primeira vista divergentes da orientação geral do Programa, a análise mais apurada dos significados atribuídos pelos sujeitos às questões, permitiu revelar uma concordância parcial dos telealunos com a proposta do curso.

Em abril de 1997, ao final da emissão da Série XI, foram aplicados aos cursistas dois exercícios sobre Língua Portuguesa e Matemática, respectivamente, e um exercício sobre os demais componentes curriculares: Ciências, Estudos Sociais e Arte. Como a aplicação foi feita em vários dias, um para cada área, o número de sujeitos sofreu pequenas oscilações, 
tendo girado em torno de cem. As respostas escritas formuladas pelos cursistas foram geralmente um pouco menos satisfatórias do que na primeira avaliação, embora a análise qualitativa dos materiais não permita uma comparação precisa entre os dois momentos. Em 1997 , eles demonstraram, em média, um domínio apenas parcial de conceitos e metodologias referentes às diversas áreas do conhecimento.

Em Língua Portuguesa, indagou-se que tipo de produto verbal os cursistas escolheriam para o trabalho em sala de aula e que abordagem utilizariam. Procurou-se averiguar também se haviam aprendido a lidar com as variantes dialetais. Utilizando parâmetros flexíveis de análise, pode-se afirmar que cerca de metade deles revelou uma compreensão razoável ou boa de conceitos e procedimentos, enquanto os demais apresentaram resultados que deixam a desejar. Verificou-se que entre os que ofereceram respostas menos satisfatórias encontra-se uma concentração maior de cursistas do interior do Ceará e de Minas Gerais, composta predominantemente de alunos do magistério. É interessante observar que em Fortaleza, onde foi registrado um grande percentual de cursistas leigos — cerca de $22 \%$ — as respostas enquadram-se na categoria dos que demonstraram melhor apreensão em algumas áreas.

Em Matemática, os exercícios versaram sobre o ensino de geometria, explorando as operações concretas e a programação das atividades da classe em consonância com o enfoque sugerido pelo Programa. Com base nos exercícios realizados, pode-se inferir que já é bastante representativa, entre os professores, a concepção de ensino que aponta para superação da metodologia baseada em repetição mecânica e que privilegia o enfoque construtivista. É proposto o envolvimento da criança em atividades tais como classificação e identificação de formas, construção de objetos e maquetes e atividades esportivas como jogar e medir in loco. De maneira geral, pode-se sugerir, no que tange aos aspectos analisados, que o Programa propicia o aparecimento de propostas que, do ponto de vista teórico, estão de acordo com os princípios por ele enunciados.

Em Estudos Sociais, a apuração do conceito de cidadania subjacente às respostas dadas pelos professores/cursistas mostra que aproximadamente um terço deles associou o conceito a construções coletivas ou a movimentos reivindicatórios. Um grupo menor reduziu-o à mera associação com os problemas sociais, sendo que em metade das respostas predominou um discurso genérico do conceito, vazio de conteúdo ou confuso. $\bigcirc$ fato de o Programa não ter discutido explicitamente o conceito, embora o tema tenha perpassado todos os programas de Estudos Sociais, pode ter contribuído para esse nível de imprecisão. Não obstante, quando se tem em conta os conteúdos selecionados, as metodologias e a justificativas elaboradas pelos professores, constata-se uma correspondência entre os temas veiculados pelo Programa e a maior parte das respostas dos cursistas. Nos exemplos mais freqüentemente escolhidos por eles para introduzir a questão, há ênfase sobretudo na cidadania ligada aos direitos sociais, o que denota uma mudança em relação a um tratamento mais tradicional dado ao tema. Os conteúdos e a metodologia mencionados não sofrem variação significativa de uma cidade para outra ou de um estado para outro. 
Em Ciências, tendo sido proposta a organização de um levantamento das condições de saúde dos alunos e familiares, as respostas revelam que a maior parte dos cursistas ainda se orienta por uma concepção restrita de saúde, privilegiando tão somente o arrolamento das principais doenças da população, das condições de higiene e saneamento básico. Tudo indica o predomínio, na prática pedagógica da maior parte dos professores, de uma visão biologizante de saúde, disseminada por intermédio dos materiais didáticos, sem que tenha sido incorporado o conceito mais amplo trabalhado pelo Programa, que relaciona a saúde à qualidade de vida da população. No que diz respeito à abordagem, predominaram as respostas nas quais somente o professor define o tipo de atividade a ser realizada, sendo muito reduzidas aquelas que propuseram a consulta e a participação dos alunos na formulação e execução do plano.

Em Arte, a intenção foi a de detectar algumas idéias e vivências dos cursistas sobre as atividades na área. Para tanto, solicitou-se que mencionassem dois exemplos de atividades e explicitassem as formas de desenvolvê-las, bem como as dificuldades encontradas nesse trabalho. Ao responderem, os cursistas tomaram como referência conteúdos e metodologias estereotipados, trocas de experiências ou "receitas" utilizadas no interior das escolas, bem como em livros didáticos. Além disso, os procedimentos metodológicos propostos foram formulados de modo fragmentado, sem um fio condutor que demonstrasse um melhor entendimento da Arte e das possibilidades de sua apreciação. Quanto à dificuldade para trabaIhar a área de Arte, a maioria apontou as carências físicas e materiais, tecendo poucas considerações sobre a dificuldade de apreensão dos conceitos.

De modo geral, em todas as áreas do conhecimento, a dificuldade de fornecer respostas que contivessem uma precisão conceitual apareceu aliada à dificuldade para indicar metodologias coerentes para a intervenção nas práticas convencionais de sala de aula. A dificuldade de compreensão de algumas questões por parte dos cursistas indica que a formação inicial precária compromete a precisão conceitual. Outras hipóteses poderiam ser levantadas nesse caso, entre as quais a de que os sujeitos não assistiram ao programa sobre o tema questionado e a de que a atuação do orientador de aprendizagem visando esclarecer determinados assuntos não foi satisfatória.

\section{INDICAÇÕES SOBRE A TRANSFERÊNCIA DE APRENDIZAGEM PARA A PRÁTICA}

As pesquisas sobre cursos ou programas de formação docente que investiguem suas repercussões até o nível da prática de sala de aula são ainda muito raras no Brasil. $\bigcirc$ estudo realizado em 1997, tomando como objeto de análise as próprias produções dos alunos dos professores que assistem a "Um Salto para o Futuro", intentou uma aproximação nesse sentido. Tendo em conta a dificuldade de realização de estudos de impacto, particularmente em se tratando de programas de amplo alcance como esse, em que são inúmeras as variáveis 
intervenientes na prática docente não passíveis de controle, as considerações aqui apresentadas devem ser tomadas apenas como indícios de tendências e os resultados discutidos, tão somente como hipóteses explicativas dos fenômenos analisados.

Procurando encontrar indícios da influência do Programa na atividade pedagógica do cursista/professor optou-se por trabalhar com classes de $3^{\text {as }}$ e $4^{\text {as }}$ séries por se tratar de um nível de escolaridade em que os alunos já dominam minimamente a leitura e a escrita. Em Belo Horizonte, foi, porém, necessário escolher uma classe de cursista/professora do $2^{\circ}$ ano do ciclo básico, uma vez que não havia professores lecionando nas séries mais avançadas na telessala visitada. Assim sendo, foram recolhidas atividades de alunos do ensino fundamental de cursistas de quatro telessalas: Fortaleza, Belo Horizonte, Itajaí e Florianópolis. Em Palmácia e Sete Lagoas, não havia professores em exercício entre os cursistas, impossibilitando a coleta de material referente às atividades das crianças.

Uma observação óbvia, mas que não pode deixar de ser feita, é a de que os materiais referentes a trabalhos de alunos do ensino fundamental constituem uma mostra restrita das práticas de sala de aula. Primeiro, por se referirem a um período curto da atividade pedagógica e, segundo, porque não contêm maiores indicações acerca do processo pelo qual foi realizada a atividade. Uma análise mais acurada sobre o impacto que uma série de TV possa ter causado na prática pedagógica demandaria um acompanhamento aprofundado das atividades docentes e discentes.

De acordo com o que foi apurado na análise dos trabalhos dos alunos do ensino fundamental, grosso modo, pode-se dizer que as atividades tendem a reproduzir as sugestões contidas no vasto mercado de livros didáticos e expressam, no mais das vezes, conceitos tradicionais ou conservadores de ensino nas diferentes áreas, indicando uma grande distância em relação às orientações veiculadas pelo Programa. Quanto à abordagem metodológica, em alguns dos trabalhos infantis é possível encontrar certa correspondência entre o que é preconizado nos programas e as atividades desenvolvidas em sala de aula, embora na maior parte dos exercícios a prática seja discrepante das orientações.

Em Língua Portuguesa, foram encontrados textos pré-fabricados, sob a forma de clichês, em redações sobre o "Dia Nacional da Mulher"; exercícios gramaticais descontextualizados e freqüentemente transpostos diretamente do livro didático. Em alguns casos, como na colagem de fotos de jornais e revistas com base nas quais as crianças criavam manchetes, parece ter havido influência dos programas que sugerem o uso de várias modalidades de textos. No entanto, como a exploração do exercício é muito mal conduzida, e, tendo em vista o escasso material analisado, não se pode pensar num efeito amplo e imediato do Programa, mas em ecos distantes do que foi veiculado.

Em Matemática constatou-se, pelo material de Belo Horizonte e Itajaí, que permitiu maior aprofundamento da análise, grande preocupação em treinar habilidades de cálculo, sendo que a seqüência das atividades nessa matéria evidencia a preocupação em seguir passos 
facilitadores. Todas as crianças da amostra usam o algoritmo convencional, não tendo sido evidenciadas formas não convencionais de cálculo. Os exercícios que utilizam cálculo mental são muito raros. Essas práticas se contrapõem aos princípios preconizados pelo Programa e aos exemplos veiculados nos vídeos, que privilegiam outras formas de fixar o cálculo e possibilitam ao aluno criar suas próprias formas de calcular.

Uma pequena percentagem de atividades nessas cidades refere-se a problemas e, menor proporção, ainda, a problemas que o aluno cria. Por sua vez, todos os problemas são estritamente numéricos. Não há apresentação de problemas que recorram à geometria. $\mathrm{Na}$ sua resolução não se observa, por parte dos alunos, tentativas de desenhar a solução, nem há indícios sobre a forma de realizar os cálculos. No entanto, segundo colocações do Programa, não se concebe mais que, no ensino da matemática elementar, se ocupe a atividade intelectual da criança com exercícios repetitivos de cálculo, desde que a máquina pode fazêlo com muito mais rapidez e eficiência. A repetição estéril de contas isoladas, sem conteúdo vivencial, pode criar na criança o enfado pela matemática e convencê-la de que esse conhecimento é totalmente desvinculado da criação humana.

A porcentagem relativamente elevada de exercícios de seqüência numérica e de ordenação, mostra uma preocupação com esse conteúdo, mas, ao que tudo indica, os conceitos parecem estar descolados de situações do cotidiano, como brincadeiras, observação de catálogos, coleções. Por outro lado, a terminologia usada nas operações matemáticas e nos exercícios sobre conjuntos evidencia também a influência marcante do livro didático na sala de aula. $\bigcirc$ tipo de exercício proposto aos alunos, pelo seu teor fechado como "arme e efetue", "resolva", "complete", "escreva a seqüência”, não leva a um processo de construção do conhecimento.

As evidências colhidas indicam ainda uma nítida defasagem entre as respostas dos cursistas e atividades realizadas pelas crianças em sala de aula, o que fica claro também quanto aos conceitos de geometria. Em Itajaí, enquanto 48\% das atividades dos alunos do ensino fundamental estão concentradas em exercícios mecânicos de cálculo escrito, 38\% das respostas aos exercícios de verificação aplicados aos cursistas citaram atividades de teor construtivista, $\bigcirc$ mesmo ocorreu em Belo Horizonte, onde a alta porcentagem de exercícios de cálculo escrito (52\%) contrasta com as respostas dos cursistas, que citaram atividades que propiciam a elaboração de novos conceitos.

Em Estudos Sociais, a maioria dos temas presentes nos exercícios não foram propostos pelo Programa, embora tenham relação com a produção de conhecimento na área. No trabalho com efemérides pode-se detectar uma certa correlação com conteúdos veiculados pelos textos e vídeos, embora as atividades não tenham sido desenvolvidas de acordo com a orientação da proposta. Os exercícios dos alunos sobre a independência do Brasil reforçam a visão da história como espaço dos heróis, ainda que o Programa tenha tentado desmistificar essa versão. Os trabalhos das crianças sobre a comemoração internacional do Dia da Mulher 
atendem às recomendações do Programa quanto à escolha do tema; neles, no entanto, são encontradas ilustrações de brinquedos considerados "masculinos" e "femininos" que tendem a reforçar os papéis tradicionais do homem e da mulher. Um pequeno texto sobre a situação carcerária sugere que a atividade pode ter relação com a questão da cidadania tratada nos programas, mas não há, nos cadernos, nenhuma indicação do trabalho pedagógico desenvolvido com os alunos.

Quanto às sugestões metodológicas preconizadas, parece ter havido maior transferência para a sala de aula. Verificou-se que há uma diversificação de textos e de fontes durante as aulas, tendo sido encontrados como de uso corrente, documentos oficiais, textos jornalísticos, literários e, principalmente, textos extraídos de material didático.

Observe-se que o número de trabalhos de Estudos Sociais nos cadernos dos alunos é muito reduzido, mostrando que o objetivo de valorizar o componente curricular e de identificálo com a área síntese, expresso pelo Programa, parece não ter conseguido alterar a pouca importância atribuída à área pelos currículos efetivamente desenvolvidos nas escolas. Esse, no entanto, parece não constituir um propósito a ser alcançado a curto prazo, de sorte que a proposta de que os Estudos Sociais se constituam no eixo da estruturação curricular da escola permanece como um estímulo para que os professores repensem o currículo a partir de princípios menos fragmentados.

Também na área de Ciências havia pouco material a ser analisado, pois além do reduzido número de alunos em cujos trabalhos escolares foram encontradas atividades da área, estas também eram pouco numerosas considerando o conjunto das atividades de cada aluno.

Entre as quatro atividades propostas nas diferentes cidades, uma delas pode ser considerada bastante relevante do ponto de vista metodológico e coerente com as tendências atuais do ensino e com as orientações adotadas em fascículos e vídeos da Série. Essas tendências apontam para a importância de desenvolver um trabalho educacional no qual os alunos entrem permanentemente em contato com os objetos e fenômenos naturais, exponham suas convicções a respeito dos fatos observados, sistematizem os dados obtidos, confrontem-nos aos dados dos colegas e de outras fontes, discutam e reelaborem suas explicações.

Em Belo Horizonte, a observação e o registro, durante um determinado intervalo de tempo, das posições do sol no céu, posição do sol e sombras em vários momentos do dia, permitiu que os alunos refletissem sobre os acontecimentos que estavam vivenciando e se manifestassem sobre eles. Os textos examinados são de autoria das próprias crianças, representando registros de suas constatações, o que possibilita perceber as diferenças nos seus modos de observar e nas associações que realizam. No material, não há, contudo, indicações sobre o trabalho posterior, que envolveria a discussão e sistematização dos dados com os alunos e o modo como continuou sendo desenvolvido o assunto. Já em outra atividade realizada por esses mesmos alunos, relacionada ao tema higiene do corpo, dos alimentos, social e mental, a abordagem restringiu-se à enumeração de dezenas de regras que normatizam o comportamento e à utilização de exercícios de fixação que privilegiam a memorização. A 
orientação teórico-pedagógica dos trabalhos dos alunos coincide, por sua vez, com as concepções identificadas nos exercícios realizados pelos professores/cursistas.

No material de Fortaleza há alguns trabalhos referentes à pesquisa sobre animais, envolvendo consulta a livros, recorte e colagem de gravuras e de textos, o que, em princípio, condiz com a orientação de ensino ativo subjacente ao Programa. Entretanto, a atividade parece não ter sido bem explorada, uma vez que as informações, copiadas ou simplesmente coladas de livros sobre o tema, trazem uma linguagem muito complexa para o nível em que estão os alunos e não há outras anotações ou indícios que revelem uma discussão da professora acerca dessas informações com as crianças.

Nos demais registros não se pode aquilatar a produção real dos alunos, isto é, as explicações que formulam acerca dos fatos observados, as soluções que apresentam para os problemas propostos, os textos que elaboram com os dados obtidos em observações/investigações. A presença de textos muito complexos ou idênticos nos cadernos, vocabulário especializado e de difícil compreensão pelas crianças sugere a utilização de estratégias sobretudo calcadas na memorização, não compatíveis com as veiculadas pelo Programa, ou que resultem em uma pobre reelaboração das informações pelos alunos.

$\mathrm{Na}$ área de Arte, os exercícios não revelam propostas específicas que envolvam a expressão artística, nem proposições que tenham como objetivo trabalhos na área, mostrando que a preocupação com a arte aparece de maneira periférica e superficial. Nos cadernos dos alunos, há indícios de realização de atividade interdisciplinar, mas, via de regra, ela desvela uma postura estética que não tem qualquer relação com os programas e textos de apoio.

O emprego do desenho apenas como possibilidade de ilustrar um assunto ou um tema determinado pela professora aparece em alguns trabalhos, sem atenção específica ao espaço para desenhar, em geral, bastante reduzido; sem a exploração de diferentes materiais e de outros encaminhamentos de ordem técnica ou expressiva. A maneira como os trabaIhos são encaminhados denota uma suposição de que a simples menção ao ato de desenhar é suficiente para que o aluno saiba expressar suas idéias, conhecimentos, isso, sem falar no recurso a imagens calcadas em estereótipos. Ou seja, encontra-se uma visão redutora da Arte, com características pedagógicas tradicionais e orientações artísticas conservadoras, semelhantes àquelas detectadas na análise das respostas dos cursistas ao exercício proposto. Essa é uma visão bastante distanciada daquela presente nos textos de apoio específicos de Arte e também nos programas integradores e multidisciplinares.

Há que se reconhecer, entretanto, que, por mais que o Programa tivesse tratado do fazer artístico e das criações artísticas nas suas diferentes formas de expressão, seria muito esperar que a freqüência e o curto período de participação do professor no telecurso fossem capazes de promover uma mudança significativa em seus hábitos culturais, artísticos e estéticos, os quais certamente demandam um tempo maior para serem consolidados. Acrescente-se, nesse caso, a própria falta de aprofundamento do Programa no que se refere à apreciação da Arte. 
As atividades registradas pelos alunos dos cursistas em seus cadernos, nas diferentes áreas do conhecimento, sugerem que há maior probabilidade de transferência para a prática quando se trata de orientações de caráter mais operacional, ao passo que os conceitos mais complexos demandariam um outro tipo de abordagem e um maior tempo de maturação para serem incorporados à prática docente. Uma outra evidência nessa direção é a afirmação, feita por várias professoras, que é freqüente a utilização do material em suas aulas, quando a sua veiculação no Programa é passível de ser empregado nas classes do ensino fundamental, permitindo supor que a transposição para a prática, quando ocorre, tende a realizar-se em condições que não exijam um grande esforço de reelaboração por parte dos docentes.

\section{CONSIDERAÇÕES FINAIS}

Em tempos em que o regime de colaboração entre o governo federal, estados e municípios para a manutenção e desenvolvimento do ensino vem sendo profundamente redefinido por força de dispositivos legais, o Programa "Um Salto para o Futuro", a despeito das dificuldades apontadas, configura-se como um modelo de cooperação entre as instâncias e mesmo entre as redes escolares e universidades, capaz de servir como instrumento que viabiliza a consecução de compromissos recíprocos no que diz respeito à formação continuada de professores.

Ao fazer uso adequado de uma feliz combinação de multimeios e intentar uma linguagem nova, com características interativas, demonstra grande potencial de adequação aos reclamos diversificados de formação de professores em serviço, ainda que não o venha explorando devidamente.

Quanto à transferência de referenciais teórico-metodológicos para a prática pedagógica, como vários dos assessores apontaram, não se pode esperar uma mudança automática e imediata do fazer docente, uma vez que se trata de um processo complexo que tem inúmeros condicionantes. $\bigcirc$ professor tem necessidade de, ao longo de um certo tempo, obter elementos capazes de lhe possibilitarem a revisão de certos pressupostos com os quais trabalha para desencadear a transposição da experiência teórica recém-adquirida para a sala de aula. A distância que separa o conhecimento teórico da aplicação prática vai sendo diminuída, preenchida, por força de ações mediadoras, fortemente imbricadas com a própria experiência docente, com as diferentes oportunidades de aprender que o professor encontra ao longo do exercício do magistério, sem o que não há como percorrer caminho algum. Nesse processo, há que se considerar também as características próprias da linguagem televisiva: motivadora, mas fragmentada, aglutinadora, mas demandatária de aprofundamento. Não se pode também esquecer as características pessoais do professor; as condições de organização e funcionamento das redes de ensino e o contexto organizacional e cultural em que a escola se insere. 
Com esse tipo de preocupacão, Sacristán (1997) alerta para a necessidade de não associar o fazer docente a paradigmas acentuadamente racionalistas, de atentar para o fato de que o professor incorpora, em sua fala, muito do discurso pedagógico contemporâneo, mas que há um grande descompasso entre o discurso e a sua prática, e de que esta está profundamente impregnada pelos valores e conflitos da sociedade abrangente, pela cultura da escola e pelo domínio efetivo dos conteúdos curriculares com os quais o professor trabalha.

Ainda que a pesquisa realizada em 1997 tenha mostrado apenas uma ligeira correspondência entre os conceitos e metodologias veiculados pelo Programa para a sala de aula, o desempenho dos cursistas nos exercícios mostra um certo nível de apreensão desses conteúdos e metodologias. Mesmo quando as respostas dos cursistas não se mostraram adequadas ao tipo de questão proposto, foi freqüente a menção aos temas abordados pelo Programa, o que pode sugerir que os cursistas estão sensibilizados para certos temas e abordagens ainda que não os dominem a contento. Esse fato, aliado à avaliação bastante positiva do Programa por parte dos agentes educacionais e dos próprios cursistas, que o consideram importante para o seu trabalho no ensino fundamental, bem como às exposições de materiais de alunos desses cursistas realizadas em vários estados, sugere que os objetivos propostos vêm sendo em parte alcançados. Esse dado parece promissor, principalmente se considerarmos a especificidade do veículo utilizado e da linguagem televisiva, uma vez que as dificuldades de transferência de conhecimentos para a prática de sala de aula são constatadas de maneira generalizada em qualquer modalidade de formação docente, seja ela inicial ou continuada, presencial ou a distância.

A curta duração das séries do Programa bem como a sua estrutura, não permitem o aprofundamento dos temas abordados de modo que o professor possa dominar o instrumental teórico básico que fundamenta os conteúdos curriculares das diferentes disciplinas, fato que se agrava devido à formação inicial, via de regra, insuficiente. A ausência desse domínio constitui, provavelmente, um elemento dificultador para que os cursistas consigam romper as fronteiras que configuram o estatuto teórico das diversas áreas do conhecimento.

Assim sendo, parece-nos que algumas Séries devem estar centradas na discussão dos novos paradigmas das diferentes áreas que compõem o currículo, sem temer o que pode parecer ausência de ousadia ao trabalharem de acordo com referenciais específicos dos respectivos campos do conhecimento, ou seja, com os estatutos disciplinares. É preciso considerar que a formação inicial dos docentes não tem levado em conta os novos referentes teóricos presentes nas propostas atuais do currículo do ensino fundamental e - ao que tudo indica, até pelas respostas dos cursistas/alunos do magistério que assistem ao Programa ainda continua distante de abordá-los de um modo mais aprofundado e competente.

$\bigcirc$ ensino de Português que os professores tiveram durante sua trajetória escolar provavelmente debruçou-se sobretudo na gramática normativa, tratada de modo descontextualizado; o de Matemática ateve-se ao domínio das técnicas operatórias e a exer- 
cícios memorísticos e mecanizados; o de Educação Artística ocupou-se com o desenvolvimento de formas estereotipadas de expressão, sem nenhuma preocupação de ampliar a capacidade de apreciar a produção artística de modo geral e assim por diante. Ora, são provavelmente essas experiências vividas que influenciam, muito mais do que outras, o fazer docente. Assim sendo, é preciso oferecer aos professores novas oportunidades de irem mais fundo na aquisição dos fundamentos teóricos e metodológicos dos componentes curriculares da escola básica, para que eles tenham condições de ultrapassar os jargões pedagógicos da moda que freqüentemente terminam incorporando ao seu discurso e possam, efetivamente, dominar aquilo que têm de ensinar. $\bigcirc$ professor não pode ensinar aquilo que não sabe.

A perspectiva de um trabalho interdisciplinar pode e deve ser mantida como alternativa metodológica para o desenvolvimento do currículo, mas não deve substituir um tratamento mais aprofundado das áreas do currículo escolar por meio de Séries específicas, haja vista a aceitação da Série voltada à alfabetização e outras mais. A interdisciplinaridade ou transdisciplinaridade, que pode fundamentar-se em um número muito variado de pressupostos e envolve rupturas epistemológicas, exige um profissional dotado de autonomia intelectual, capaz de compreender as diferentes perspectivas teórico-metodológicas e de optar por um caminho próprio ou menos convencional para o desenvolvimento de atividades de sala de aula.

Em suma, o Programa constitui um modelo inovador de educação a distância para os professores do ensino fundamental, com algumas características que revelam grandes potencialidades de utilização no campo da formação continuada de docentes. No entanto, deve continuar sofrendo reformulações para permitir um diálogo competente com aqueles a quem se dirige.

\section{REFERÊNCIAS BIBLIOGRÁFICAS}

BARRETTO, E. S. de S. Capacitação a distância de professores do ensino fundamental no Brasil. Educação e sociedade. Campinas, v. 13, n.59, p.308-29, ago. 1997.

BRASIL. Lei de Diretrizes e Bases da Educação Nacional. Lei n 9.394, de 1996. Brasília: Câmara dos Deputados, Coordenação de Publicações, 1997.

BRASIL. SEEC/MEC. Censo Escolar, 1998.

CANDAU, V. M. F. Formação continuada de professores: tendências atuais. In: REALI e MIZUKAMI (orgs.). Formação de professores: tendências atuais. São Carlos: Ed. UFSCar, 1996.

CEARÁ. Secretaria da Educação. Todos pela educação de qualidade para todos - 1995/I 998. Fortaleza: Secretaria da Educação, s.d.

COSTA, A. L. M. Educação a distância: uma alternativa para o fortalecimento do ensino municipal. 
Tecnologia Educacional, v.22, n. I 19/120, p.42-5, jul./out., 1994.

FRADKIN, A. SINTED: O Sistema nacional de televisão educativa. Tecnologia Educacional, v.10, n.38, p.47-9, jan./fev. 1981.

FUNDAÇÃO CARLOS CHAGAS. Avaliação do Programa "Um salto para o Futuro". Estudo piloto do impacto. São Paulo: FCC, 1997. [Relatório de Pesquisa.]

. O Programa "Um Salto para o Futuro": avaliação externa. São Paulo: FCC, 1993. [Relatório de Pesquisa.]

GARCIA, E. W. Legislação, políticas públicas e gestão para o ensino a distância. Tecnologia Educacional. Rio de Janeiro, v.25, n.139, p. 16-9, nov./dez, 1997.

GUTIERREZ, F., PRIETO, D. Mediação Pedagógica, Educação a Distância Alternativa. Campinas: Papirus, 1994.

HAWKINS, J. O uso de novas tecnologias na educação. Revista Tempo Brasileiro. Rio de Janeiro, n.120, p.57-69, 1995.

LENOIR, Y. A importância da interdisciplinaridade na formação de professores do ensino fundamental. Cadernos de Pesquisa. São Paulo, n. I02, p.5-22, nov. 1997.

MAGALHÃES, M. T. P. A televisão no processo de ensino aprendizagem. Marília, 1997. Dissert. (mestr.) FFC-UNESP.

MARTíN-BARBERO, J. América Latina e os anos recentes: o estudo da recepção em comunicação social. In: SOUZA, M. W. (org.) Sujeito, o lado oculto do receptor. São Paulo: Brasiliense, 1995.

NISKIER, A. Políticas de tecnologia educacional. Educação Brasileira, Brasília, v. I , p.6I-85, 10 sem., 1988.

PINTO, M. Um Salto para o Futuro. Tecnologia Educacional, v.25, n. I32/I33, p.35-7, set./ dez., 1996.

ROSSETTI, F. Ensino a distância sai caro. Folha de S. Paulo, Caderno São Paulo, p. 3-5, de I I/10/1998.

SACRISTÁN, J. G. Tendências investigativas na formação de professores. Caxambu: ANPEd, 1997. (Exposição em Mesa Redonda na 20a Conferência Anual da ANPEd.)

SARAIVA, T. Educação a distância no Brasil: lições de história. Em Aberto. Brasília, v.6, n.70, p. 17-27, abr./jun. 1996. 